Dhaka Univ. J. Biol. Sci. 31(1): 137-146, 2022 (January) ～DOI: https://doi.org/10.3329/dujbs.v31i1.57922

\title{
COMPARISON BETWEEN THE PREDICTED AND EXPERIMENTAL L-GLUTAMIC ACID PRODUCTION BY FREE CELLS OF CORYNEBACTERIUM GLUTAMICUM X680 USING MATHEMATICAL MODEL
}

\author{
SubhadeEp Ganguly* And SMaranika PATtNaIK ${ }^{1}$ \\ Department of Physiology, Vidyasagar College, 39, Sankar Ghosh Lane, \\ Kolkata-700006, West Bengal, India
}

Key words: L-glutamic acid, Corynebacterium glutamicum, Experimental, Non-growth

\begin{abstract}
The present investigation was undertaken to predict the amount of Lglutamic acid production by a mutant Corynebacterium glutamicum X680 using mathematical model emphasizing Bona and Moser (1997) hypotheses. This model was able to predict the experimental data with the minimum value of sum squares of weighted residues (sswr) 0.161 . This model claimed that an increase in non-growth associated product formation coefficient led to maximum negative impact on L-glutamic acid production.
\end{abstract}

\section{Introduction}

Recent trends in biotechnology are intimately associated with the applications of mathematical models. The models principally involve two kinetic parameters: the yield coefficient and the kinetic rates ${ }^{(1,2)}$. Bona and Moser (1997) introduced the mathematical modeling on the L-glutamic acid fermentation(2). Bona and Moser (1997) studied the modeling considering biotin limitation obeying the formal kinetic approach ${ }^{(3)}$. The mathematical model for bacterial growth followed the growth model of Yamashita et al. (1969) with extension model of Bergter and Knorre (1972) for the log phase of bacterial growth and the production being proportional to the biomass ${ }^{(5,6)}$. The model was based on the assumptions that the fermentation is biotin limited and the substrate was supplied in excess. Bona and Moser (1997) hypothesized another mathematical model of Lglutamic acid fermentation using Corynebacterium glutamicum under biotin limitation and proposed a kinetic model with the assumption of the cellular maturation with the batch process under sufficient supply of substrate which has no effect on the kinetic parameters of the fermentation trials considering the role of biotin as the pivotal role ${ }^{(4)}$. Zhang et al. (1998)(7) applied empirically non-linear time-dependent kinetics for cellular growth, substrate utilization and product formation. In this present study, a kinetic model has

\footnotetext{
*Address for correspondence: <res_biol@rediffmail.com>,<smaranika2010@gmail.com>. ${ }^{1}$ Department of Biotechnology and Bioinformatics, Medical Biotechnology Laboratory, Sambalpur University, Jyoti Vihar, Burla, Odisha-768019, India.
} 
been suggested for modeling fermentation of L-glutamic acid by a mutant Corynebacterium glutamicum X680.

\section{Materials and Methods}

Microorganism: Corynebacterium glutamicum X680, a biotin auxotroph developed in our laboratory by induced mutation in my previous investigation was used for this study ${ }^{(8)}$.

Composition of synthetic production medium and other culture conditions: $\mathrm{pH}$ 7.0, incubation period- $72 \mathrm{~h}$; medium volume-, $30 \mathrm{ml}$, inoculum size- $4 \%\left(8 \times 10^{6}\right.$ cells $)$, inoculum age- $48 \mathrm{~h}$, temperature- $30^{\circ} \mathrm{C}$, agitation rate- $150 \mathrm{rpm}$, glucose- $12 \%$, urea- $1 \%$, calcium carbonate- $4 \%$, potassium dihydrogen phosphate- $0.3 \%$, dipotassium hydrogen phosphate- $0.3 \%$, magnesium sulphate heptahydrate- $2 \mathrm{mg} \%$, zinc sulphate heptahydrate- $10 \mu \mathrm{g} / \mathrm{ml}$, ferrous sulphate heptahydrate- $10 \mu \mathrm{g} / \mathrm{ml}$ and biotin- $3 \mu \mathrm{g} / \mathrm{ml}$.

Analysis of L-glutamic acid: Descending paper chromatography was employed for qualitative detection of L-glutamic acid in the broth. The chromatographic run was conducted for $16 \mathrm{~h}$ using a solvent system include n-butanol:acetic acid: water (2:1:1) and then spots were visualized by spraying $0.2 \%$ ninhydrin in acetone. The quantitative estimation was done by colorimetric estimation $\operatorname{method}(9,10)$.

Estimation of dry cell weight (DCW): The cell paste was obtained from the fermentation broth by centrifugation and dried at $100^{\circ} \mathrm{C}$ until constant weight was obtained ${ }^{(11)}$.

Estimation of residual sugar: Residual sugar was determined by the DNS method as proposed by Garriga et al.(17).This method examined the presence of carbonyl group $(C=O)$ of reducing sugar. Functional group of the reducing sugar is oxidized and 3,5dinitrosalicylic acid (DNS) is reduced to 3-amino-5-nitrosalicylic acid under alkaline conditions:

Aldehyde + 3,5-dinitrosalicylic acid ---> Carboxyl group + 3-amino-5-nitrosalicylic acid

Because, the dissolved oxygen itself can interfere with the oxidation of glucose, sodium sulfite (not necessary for color development) is added to the reagent to absorb the dissolved oxygen.

In this procedure, $3 \mathrm{ml}$ of DNS reagent was added to $3 \mathrm{ml}$ of glucose sample in a lightly capped test tube. The test tube was heated at $90^{\circ} \mathrm{C}$ for 10 minutes to develop red brown color. $1 \mathrm{ml}$ of $40 \%$ sodium tartrate (Rochelle salt) solution was added to stabilize the color. The test tube was cooled to room temperature in a cold water bath and the absorbance was recorded with a spectrophotometer at $575 \mathrm{~mm}{ }^{(12)}$.

Development of Mathematical model: The following kinetic equations are used which are available in literature:

$$
\frac{d}{d t}[B]=\mu_{\max } \frac{[S]}{[S]+K_{i}\left(1+K_{i}\right)}
$$


where, $B=$ Bacterial cell mass; $\mu_{\max }=$ maximum specific growth rate $\left(\mathrm{h}^{-1}\right) ;[S]=$ substrate concentration $(\mathrm{mg} / \mathrm{ml}) ; \mathrm{K}_{\mathrm{g}}=$ Monod growth constant for substrate $\left(\mathrm{mg} \cdot \mathrm{ml}^{-1}\right)$; $\mathrm{K}_{\mathrm{i}}=$ inhibition constant for growth by product $(\mathrm{mg} /)$.

$$
\frac{d}{d t}[S]=-\frac{1}{Y_{b}} \cdot \frac{d B}{d t}-\frac{1}{Y_{P}} \cdot \frac{d P}{d t}
$$

where, $Y_{b}=$ yield Cofficient biomass from substrate $(\mathrm{mg} / \mathrm{mg}) ; Y_{\mathrm{p}}=$ yield Cofficient product from substrate $(\mathrm{mg} / \mathrm{mg}) ; \mathrm{P}=$ product Concentration $(\mathrm{mg} / \mathrm{mg})$.

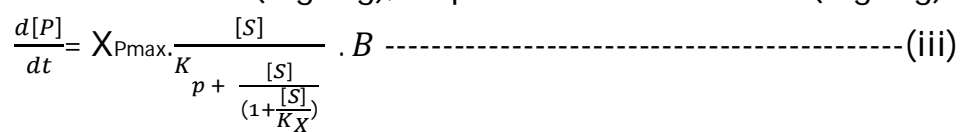

where, $\mathrm{X}_{\mathrm{Pmax}}=$ maximum specific production rate; $\mathrm{Kp}=$ Monod product constant for the substract; $\mathrm{Kx}=$ Monod growth constant for the specific biotin concentrstion $(\mu \mathrm{g} /)$.

Using the logistic model, it can be written as:

$$
\frac{d B}{d t}=\mu_{\max }[S]\left(1-\frac{[B]}{[B m]}\right)-(i v)
$$

where, $\left[\mathrm{B}_{\mathrm{m}}\right]=$ maximum biomass concentration.

This equation is substrate-independent. The cellular growth can be predicted from the following equation:

$$
\mathrm{B}=\frac{[\mathrm{Bo}][\mathrm{Bm}]^{\mathrm{e}} \mathrm{emax}^{\mathrm{max}}}{[\mathrm{Bm}]-[\mathrm{B} 0]+[\mathrm{Bm}]^{\mathrm{e} \max -1}}
$$

where, $\mathrm{B}_{\mathrm{o}}=$ initial biomass concentration ( $\left.\mathrm{mg} / \mathrm{mg}\right)$.

This equation is applicable when $t=0$ and $B_{0}=B_{m}$, thus, it shows the relationship between cellular growth and fermentation time. $\mu_{\mathrm{m}}$ and $\mathrm{B}_{\mathrm{m}}$ can be estimated from nonlinear regression. According to Luedeking- Piret model, the rate of L-glutamic acid production is linearly related to both bacterial cell mass $(B)$ and growth rate $(\mathrm{dB} / \mathrm{dt})$ as:

$$
\frac{d P}{d t}=\mathrm{C} \cdot \frac{d B}{d t}+\gamma \mathrm{B}------(v i)
$$

where, $\mathrm{C}=$ growth associated product formation coefficient $(\mathrm{mg} / \mathrm{mg}$ ).

L-glutamic acid production is associated with bacterial growth rate only when $C \neq 0$ and $\gamma+0$. As the substrate utilized for cellular growth, maintenance of the cells as product formation, thus it can be written as:

$$
-\frac{d[S]}{d t}=\frac{1}{Y_{b}} \cdot \frac{d B}{d t}+1 Y_{\mathrm{p}} \cdot \frac{d[P]}{d t} \cdot \mathrm{m}_{\mathrm{c}} \mathrm{B}
$$

where, $\mathrm{Y}_{\mathrm{p}}=$ yield coefficient product from substrate $(\mathrm{mg} / \mathrm{mg}) ;[\mathrm{P}]=$ concentration of product (mg.mg-1); $\mathrm{m}_{\mathrm{c}}=$ Maintenance Coefficient $(\mathrm{mg} / \mathrm{mg})$.

This equation describes the utilization of substrate for L-glutamic acid production, bacterial growth and cellular maintenance.

Product formation can be calculated from the Bona and Moser's formula as follows:

$$
\mathrm{P}=\mathrm{C}\left[\mathrm{B}-\mathrm{B}_{\mathrm{o}}\right]+\frac{\mathrm{Bm} \gamma}{\mu \mathrm{max}} \cdot \ln \frac{\mathrm{Bm}-\mathrm{Bo}}{\mathrm{Bm}-\mathrm{B}}
$$


where, $\mathrm{B}=$ biomass concentration at a given time $\left(\mathrm{mg} \cdot \mathrm{mg}^{-1}\right) ; \mathrm{B}_{\mathrm{m}}=$ maximum biomass $\left(\mathrm{mg} \cdot \mathrm{mg}^{-1}\right) ; \mathrm{B}_{\mathrm{o}}=$ initial biomass $((\mathrm{mg} / \mathrm{mg})$.

The sum squares of weighed residues for estimation of kinetic parameters were examined using the following formula:

$$
\mathrm{Sswr}=\sum_{X=0}^{a} \sum_{Y=0}^{b} \frac{\mathrm{D}^{2} \mathrm{XY}}{\mathrm{W}^{2} \mathrm{Y}}
$$

where, $a=$ number of experimental data; $b=$ number of process variable; $D x y=$ difference between the model and experimental data of $X^{\text {th }}$ variable in $Y^{\text {th }}$ experimental point; $\mathrm{WY}=$ maximum weight of variable $(\mathrm{mg} / \mathrm{mg})]$.

The standard error of mean (SEM) of the variable was calculated using the following formula:

$$
\operatorname{SEM}(\Delta)=\frac{1}{a} \sum_{X=1}^{a} \Delta \mathrm{XY} \text {------------(x) }
$$

The Residual Variance of the error (R) was calculated as follows:

$$
\mathrm{R}=\frac{1}{a-1} \sum_{X=1}^{a}\left(\partial_{\mathrm{XY}-\Delta}\right)^{2}
$$

The statistical adequacy for the acceptance of this model can be calculated as follows:

The definition of statistic ' $\lambda$ ' can be presented as follows:

$$
\lambda=\frac{(a-b) a}{(a-1) b}=\sum_{Y=1}^{b} \frac{\mathrm{D}_{\mathrm{b}}{ }^{2}}{\mathrm{R}}
$$

The end point deviation (EPD) in L-glutamic acid fermentation was estimated as follows:

$$
\mathrm{EPD}=\frac{[P]-[P]_{C}}{[P]_{C}} \times 100--
$$

where, $[\mathrm{P}]=$ product concentration in experiment $(\mathrm{mg} / \mathrm{mg}) ;[\mathrm{P}] \mathrm{c}=$ product concentration in control ( $\mathrm{mg} / \mathrm{mg}$ ).

The mathematical problem regarding this modeling was solved using Microsoft EXCEL ${ }^{(3,4)}$.

Statistical analysis: All the data were expressed as mean \pm SEM. Data were analyzed using One Way ANOVA followed by Dunett's post hoc multiple comparison test using a soft-ware Prism 4.0.

All the chemicals used in this study were of analytical reagent (AR) grade and were obtained from Mark. Borosil glass goods and triple distilled water were used.

\section{Results and Discussion}

Kinetic analysis of the bacterial growth: A comparative study of simulatory and experimental data of Bona and Moser (1997)(2) model and simulatory data of this present investigation was depicted in Fig. 1. The simulatory data of this present investigation fitted better with the simulatory model as proposed by Bona and Moser (1997)(3). 

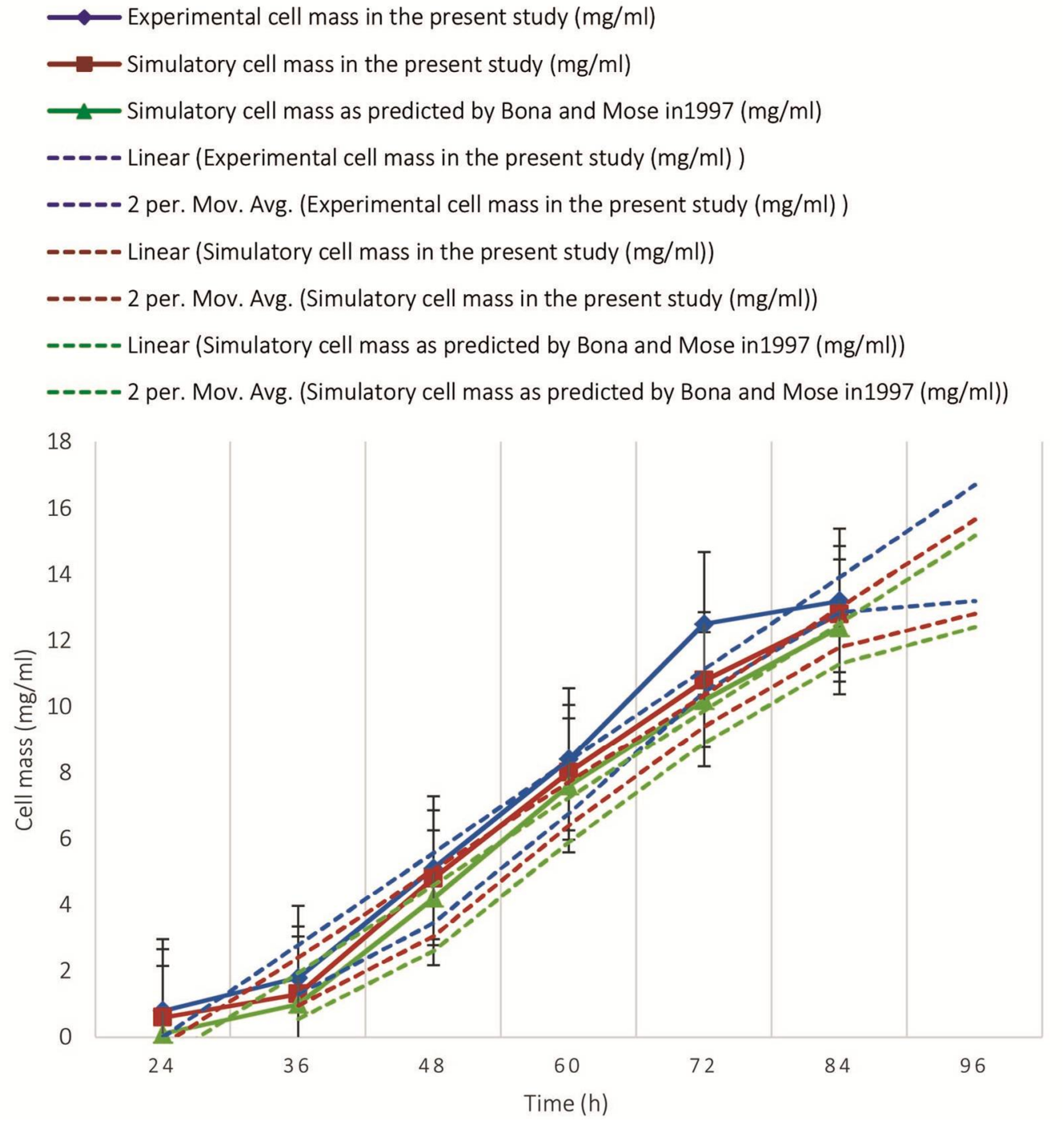

Fig. 1. Comparison of simulatory vs experimental data for cell mass in the present investigation and experiments of Bona and Moser $(1997)^{(3,4)}$

\section{Kinetic analysis of the product formation}

By putting the experimental data to equation (8) and considering the concepts of Bona and Moser (1997)(2,3), following equations can be derived:

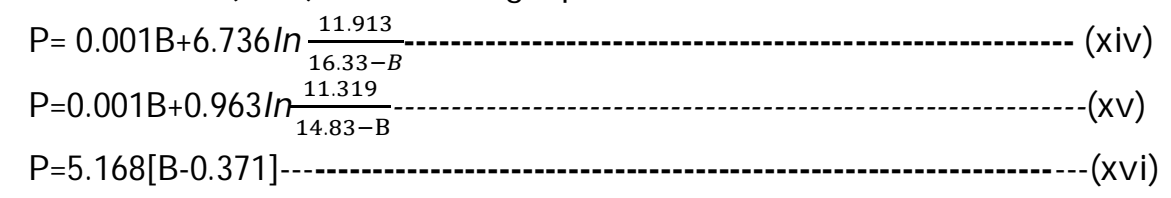


Thus, the production of L-glutamic acid by this mutant was related to the cell growth in a very complex manner. The product formation in the present study was satisfactory compare to the models as proposed by Bona and Moser (1997)(2,3) (Fig. 2).

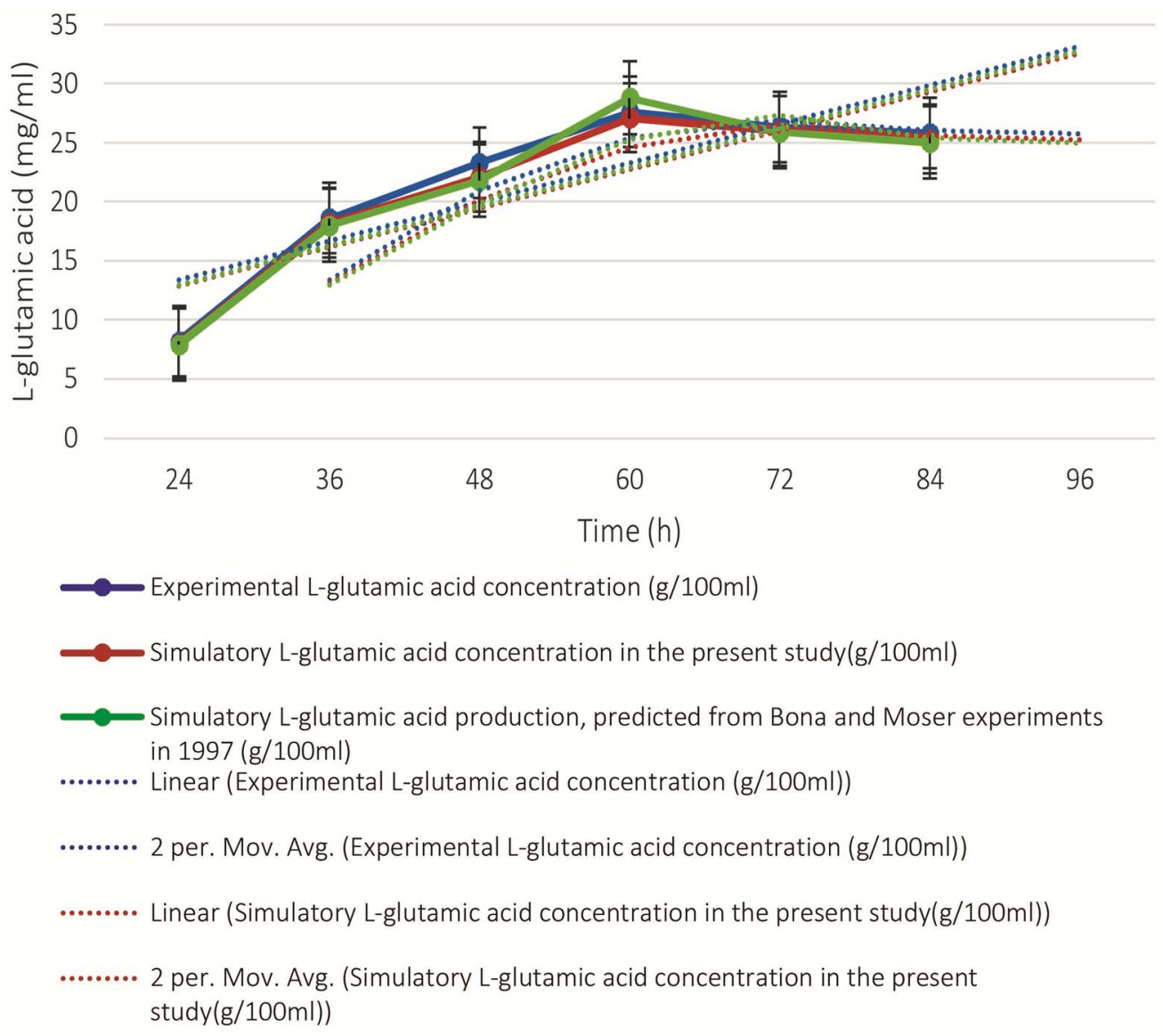

Fig. 2. Comparison of simulatory vs experimental data for L-glutamic acid production by Corynebacterium glutamicum X680, collected from present study and experiments of Bona and Moser (1997)(2,3)

\section{Kinetics of substrate uptake}

Fig. 3 shows the pattern of substrate uptake at different time intervals. Maximum uptake was resulted at $72 \mathrm{~h}$ of incubation.

\section{Product formation as a function of cell mass and substrate uptake}

In this present study, the basic aspects, namely: bacterial growth (B), product formation $(\mathrm{P})$ and substrate uptake [S] were considered as presented in Table 1. 


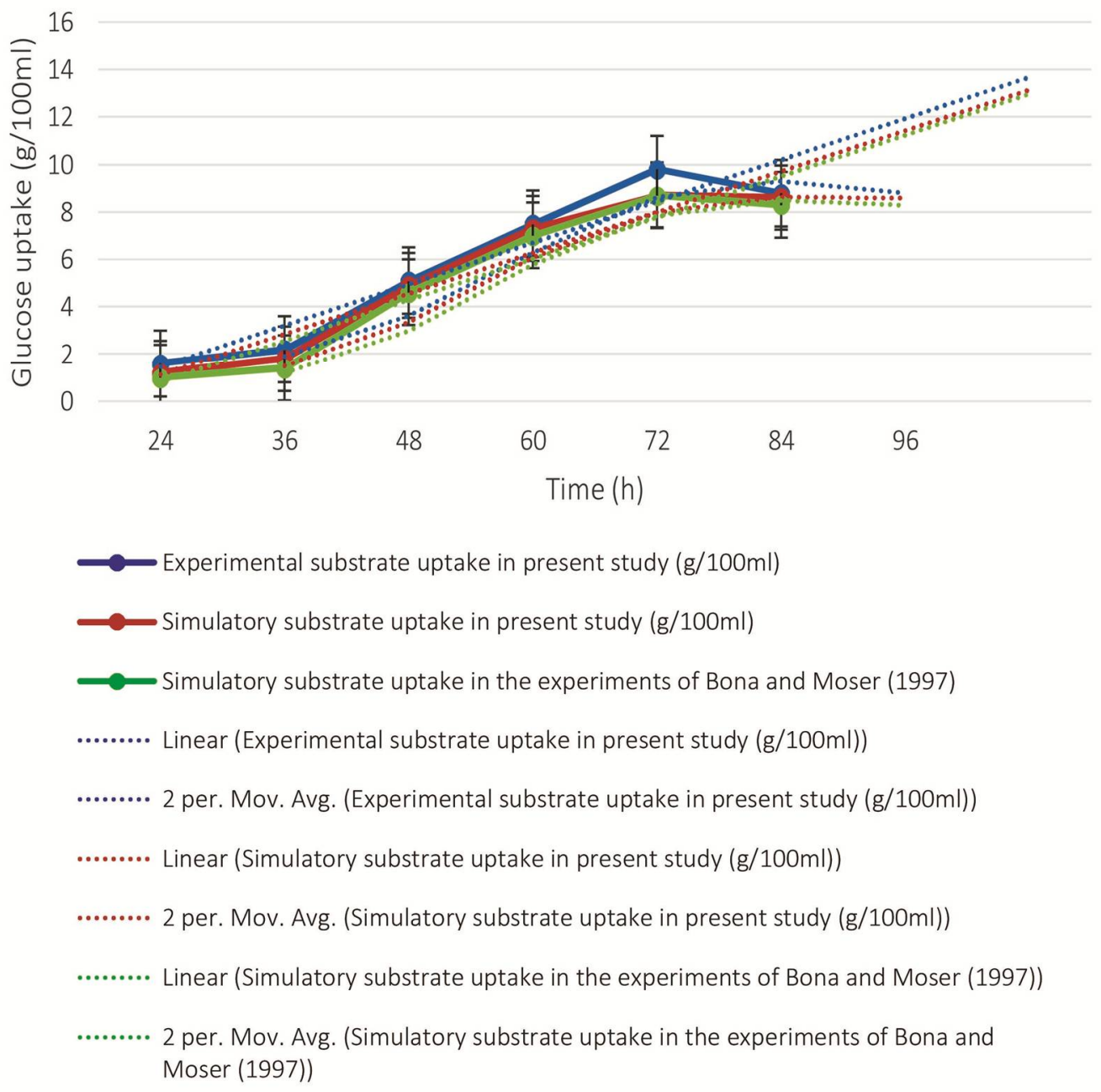

Fig. 3. Comparison of simulatory vs experimental data for substrate uptake by Corynebacterium glutamicum X680 collected from present study and experiments of Bona and Moser (1997)(3,4)

L-glutamic acid production was obtained in stationary phase. The calculated value of $\mathrm{B}_{0}$ was lower than the experimental value probably due to the viability of cells. This model depicts better resolution than Bona and Moser's model. L-glutamic acid production is associated with bacterial growth in a very complex manner.

Sensitivity analysis for L-glutamic acid production by the Corynebacterium roseum X680: It was conducted to assess the validity of the newly developed model and to evaluate the impacts of kinetic parameters on the production of L-glutamic acid. This section of study examined the impact of end point deviation (ED) of L-glutamic acid production at given 
points $\pm 5 \%$ and $\pm 10 \%$ respectively on each kinetic parameters. The ED was determined using the following formula:

$$
\mathrm{ED}=100 x \frac{\text { Product endat 5\%-Prodtct end control }}{\text { Product end control }}
$$

Where, Product end 5\% =L-glutamic acid concentration (in $\mathrm{mg} / \mathrm{ml}$ ) at $60 \mathrm{~h}$ given a $5 \%$ increase in at least one of the kinetic parameters in the rate equations; and Product end control = L-glutamic acid concentration (in $\mathrm{mg} / \mathrm{ml}$ ) at $60 \mathrm{~h}$ in the resent study.

Table 1. Compare between present model and Bona and Moser's model.

\begin{tabular}{llcc}
\hline Kinetic parameters & & Present model & $\begin{array}{c}\text { Bona and Moser's } \\
\text { model }(1997)^{(3,4)}\end{array}$ \\
\hline Bacterial growth & $\mu_{\max }$ & 0.481 & 0.2 \\
& $\mathrm{~B}_{\mathrm{m}}$ & 11.31 & 0.3 \\
Substrate utilization & $\mathrm{B}_{\mathrm{o}}$ & 0.062 & 0.7 \\
& $\mathrm{Y}_{\mathrm{b}}$ & 0.872 & 0.4 \\
\multirow{2}{*}{ L-glutamic } & $\mathrm{Y}_{\mathrm{p}}$ & 0.483 & 0.5 \\
production & $\mathrm{m}_{\mathrm{c}}$ & 0.211 & 0.2 \\
& $\mathrm{C}$ & 0.082 & 231 \\
Error values & $\mathrm{sswr}$ & 0.149 & 0.664 \\
\hline
\end{tabular}

Values of sum squares of weighted residues for the present model and the Bona and Moser (1997)(3) model were 0.149 and 0.664 respectively ${ }^{(3)}$. Thus, the present model was more suitable than the model of Bona and Moser (1997b) ${ }^{(4)}$.

The percentage changes in the estimation of L-glutamic acid were depicted in Table 2 as follows,

Increase in $\gamma$ has negative effect on ED, leading to inhibition of L-glutamic acid fermentation. Here, $5 \%$ and $10 \%$ increase in $\gamma$ lead to a $2.617 \%$ and $3.511 \%$ decrease in ED respectively. A $5 \%$ and $10 \%$ elevation of $\mathrm{B}_{\mathrm{m}}$ led to $0.011 \%$ and $0.02 \%$ reduction in $\mathrm{ED}$, and thus, inhibition of L-glutamic acid production. $\mu_{\max }$ and $\mathrm{C}$ exhibit negative impact on ED and thus on L-glutamic acid fermentation. But other kinetic parameters had no effect on L-glutamic acid production in this present study. Thus, the elevation of non-growth associated L-glutamic acid fermentation-coefficient caused maximum detrimental effect on L-glutamic acid fermentation.

Zhang et al. (1998) postulated a time-dependent kinetic model for L-glutamic acid production $^{(7)}$. Bona and Moser (1997) ${ }^{(2,3)}$ applied three types of kinetic models (namely: (1) logistic models and Monod Kinetics to describe the log phase of bacterial growth, (2) a model describing product mediated growth inhibition and substrate mediated production repression and (3) a model describing biotin-dependent growth and the 
retention term for lag-phase and cell maturation) to described L-amino acid fermentation ${ }^{(3,4)}$. Khan et al. (2005) applied Monod equation to develop a model for the

Table 2. ED in response to $\pm 5 \%$ and $\pm 10 \%$ changes for each kinetic parameters in the present model.

\begin{tabular}{lllll}
\hline \multirow{2}{*}{$\begin{array}{l}\text { Kinetic } \\
\text { parameters }\end{array}$} & $+5 \%$ & $-5 \%$ & $+10 \%$ & ED $_{10 \%}$ \\
\cline { 2 - 5 } & - & - & - & $-10 \%$ \\
\hline$B_{o}$ & -0.0168 & 0.0191 & -0.082 & - \\
$B_{m}$ & -0.044 & 0.016 & -0.021 & 0.046 \\
$\mu_{\max }$ & - & - & - & 0.019 \\
$Y_{b}$ & - & - & - & - \\
$Y_{p}$ & - & - & - & - \\
$m_{c}$ & -0.0182 & 0.016 & -0.004 & - \\
$C$ & & & & 0.009 \\
\hline
\end{tabular}

growth of Corynebacterium glutamicum for L-glutamic acid production under product inhibition(13). They also used model of Bona and Moser (1997)(3) and the model of Zhang et al. $(1998)^{(7)}$ to explain their experiment ${ }^{(3,7)}$. The model of Bona and Moser (1997)(4) could not correlated as it was obtained with high glucose concentration, as their model suffered from substrate inhibition during the initial phase of fermentation up to $18 \mathrm{~h}^{(4)}$. Suresh et al (2005) applied kinetic modeling and sensitivity analysis of kinetic parameters for Lglutamic acid production by Corynebacterium glutamicum(14). This study revealed that an increase in non-growth associated L-glutamic acid formation coefficient resulted negative impact on L-glutamic acid production. Dynamic metabolic simulation model was also used for L-glutamic acid production analysis by Escherichia coli MG1655 $\Delta$ sucA(15). Naggar et al. (2019) applied mathematical modeling for process optimization of protein drug and uricase production by Aspergillus welwitschiae strain 1-4(16).

\section{Conclusion}

This model was able to fit the experimental data with the minimum value of sswr of 0.161 compare to that of 0.664 as proposed by Bona and Moser (1997)(3). This model proposed that an increase in non-growth associated product formation coefficient resulted maximum negative impact on L-glutamic acid production. This prediction will be helpful for improving the industrial production of L-glutamic acid using this mutant strain.

\section{References}

1. Georgiev T, V Ivanova, J Kristeva, K Todorov, I Dimov, and A Ratkov 2006. Modelling of Fedbatch Fermentation Process with Droppings for L-lysine Production. Bioautomation, 4: 12. 
2. Bona R and A Moser 1997. Kinetic Modeling and Sensitivity Analysis of Kinetic Parameters for LGlutamic Acid Production Using Corynebacterium glutamicum. Bioproc. Eng. 17(A89): 1-14.

3. Bona R and A. Moser 1997. Modelling L-glutamic acid production with Corynebacterium glutamicum under biotin limitation. Acta Biotechnologica, 17(4): 327-337.

4. Yamashita S, H Hoshi, and T Inagaki 1969. In: Perlman D (Ed), Fermentation Advances, Vol. 1. Academic Press, New York, pp. 441-463.

5. Bergter F and W. Knorre 1972. Computersimulation von Wachstum und Produktbildung bei Saccharomyces cerevisiae. Zeitschrift Fur Allgemeine Mikrobiologie 12(8): 613-629.

6. Zhang XW, T Sun, ZY Sun, X Liu, and DX Gu 1998. Time-dependent kinetic models for glutamic acid fermentation. Enz. Microbialal. Technol. 22: 205-209.

7. Ganguly S 2019. Isolation, Characterization and Improvement on a wild strain of Corynebacterium glutamicum for L-glutamic acid production. J. Ind. Chem. Soc. 96(6): 705-710.

8. Nampoothiri KM and A Pandey 1998. Immobilization of Brevibacterium Cells for the production of L-glutamic acid. Biotechnol. Lett. 63(1): 695-719.

9. Ganguly S and Banik AK 2010. Induced mutation and selection of high yielding strain of Micrococcus glutamicus for glutamic acid production. J. Indian Chem. Soc. 87(6): 717-721.

11. Shah AH, A Hameed, S Ahmad and GM Khan (2002). Optimization of culture conditions for L-lysine fermentation by Corynebacterium glutamicum.Online J. Biol. Sci. 2(3): 151-156.

12. Garriga M, M Almaraz, and A Marchiaro 2017. Determination of reducing sugars in extracts of Undaria pinnatifida (harvey) algae by UV-Visible spectophotometry (DNS Method). Actas de Ingeniería, 3: 173-179.

13. Khan NS, IM Mishra, RP Singh, and B Prasad 2005. Modeling the growth of Corynebacterium glutamicum under product inhibition in L-glutamic acid fermentation. Biochem. Eng. J. 25(2): 173-178.

14. Suresh S, NS Khan, VC Srivastava and IM Mishra 2005. Kinetic modeling and sensitivity analysis of kinetic parameters for 1-glutamic acid production using Corynebacterium glutamicum. Int. J. Chem. React. Eng. 7: Article A89.

15. Nisho Y, S Ogishima, M Ichikawa, Y Yamada, Y Usuda, T Masuda and H Tanaka 2013. Analysis of L-glutamic acid fermentation by using a dynamic metabolic simulation model of Escherichia coli. BMC Systems Biology, 7: http://www. Biomedcentral.com/1752-0509/7 92.

16. EI-Naggar NA, EM EI-Weshy, EA Metwally and AA Sherief 2019. Mathematical modeling for bioprocess optimization of a protein drug, uricase, production by Aspergillus welwitschiae strain 1-4. Scientific Reports, 9:12971, https://doi. org/10.1038/s41598-0194-492011 . 